\title{
THE PUBLIC RELATIONS PRACTICE AS DISCOURSE TECHNOLOGY FOR ORGANIZATION'S HEGEMONY THROUGH CORPORATE SOCIAL RESPONSIBILITY PROGRAMS IN COAL MINING INDUSTRY OF EAST KALIMANTAN, INDONESIA
}

\author{
Juwita Rina \\ Faculty of Social and Political Science, University of Mulawarman, Indonesia \\ E-mail: rinajuwita@fisip.unmul.ac.id \\ ORCID: 0000-0003-3133-3919
}

\begin{abstract}
It is well emphasized in the literature that PR practice is largely determined by the sociopolitical and economic context in which it works. However, it is argued that PR practice is slowly changing to adapt to specific contexts and needs, especially for the elite groups it serves. This study discusses how PR practice as a discourse technologist through CSR initiatives programs works in the coal mining industry in East Kalimantan, Indonesia. By using Foucauldian Discourse Analysis, this article assesses the dominant themes that arise from the interview with PR and CSR practitioners and the CSR Reports from two coal mining companies which awarded several CSR awards in national and international level. The study found two dominant PR practices as corporate discourse technologists, which are to promote CSR to improve corporate competitiveness and to act as CSR programs advisor that are subjected to PR ethical standards dilemma.
\end{abstract}

\section{KEY WORDS}

PR practice, discourse technologist, mining industry, program.

The Public Relations (PR) involvement as the company's representation plays an important role in maintaining the organization's reputation, one of which is through the Corporate Social Responsibility (CSR) initiatives. CSR is also considered by many as one of the strategies implemented by business actors as a solution to the existing socio-economic problems, such as the high rate of poverty, hunger and poor quality of education particularly in developing countries. However, along with global developments, public awareness is also increasingly overseeing business behaviour that is often irresponsible and creates more social and environmental scandals.

There is a number of examples that show the adverse effects of unethical and irresponsible corporate practices that implicates not only to internal but also external stakeholders that trigger public demands of the ethical and socially responsible business practices. In Indonesia, the impact of the hot mudflow in Sidoarjo, East Java due to the operation of PT Lapindo Brantas since 2006 ago have inundated residential, agricultural and industrial areas until present time; the ongoing social conflict of the Papuan with PT Freeport Indonesia Incorporation since 1974; and the environmental pollution in Buyat Bay conducted by PT Newmont Minahasa Raya in 2004 ago are some of the serious problems that show the ugly face of corporate practice. East Kalimantan is also known for its natural resources and hosts many large corporations operating at both national and international levels. This condition makes this area is also inseparable from social and environmental polemics due to corporate operations that merely consider the business interests. One of the growing industry is coal mining as it contributes as one of the biggest income which produces around 82.87 million tons in 2017 (Republika, 20/02/2018). This increasing coal production process has caused a lot of dilemmas as it increases the damage to the biodiversity of the forest and creates environmental disasters due to land expansion form mining activities. Many water sources are reported the loss and more frequent droughts and natural disasters happened (Fitryarini, Juwita \& Purwaningsih, 2015; VOA Indonesia, 2013). The death of 32 children in the last three years who freely played in the ex-mining area that were not reclaimed by the 
company has attracted a lot of public attention (Apriando, 2018). Not to mention the industrial waste that impairs the communities surround the sites, and disrupts the economic and social activities of the locals (Suastha \& Kandi, 2016). Even the problem of life inequality between the mining workers and local communities creates another issue of injustice due to a large number of people lost their livelihoods and then forced to become labourers in their own villages often caused particular sustainable social problems (JATAM, 2016).

As much as mitigation efforts carried out by corporations always involve PR practitioners as well as assisted by other elements in the organization. In doing so, to keep the social acceptance and to maintain the company existence as part of the community entity, CSR initiatives emerge to compensate and to overcome such problems. However, a number of studies claim that majority of CSR initiatives implemented by the company is merely a charity program designed to cushioned public debate on the dark side of this coal mining industry (Tribun Kaltim, 2016). CSR, therefore, did not to purely empower the community as the essence of CSR that many experts claim, but merely to treat the social and environmental damage occurred in place.

By referring to Foucault which later conceptualized by Motion and Leitch, it is assumed that PR practitioner oft to act as discourse technologist whom actively play in particular discourse transformation through the texts production and distribution for the sake of the company (Motion \& Leitch, 1996; Motion \& Weaver, 2005). PR involvement in CSR programs is quite dilemmatic as PR works to support the hegemonic power of the corporate system. This later impacts on the failure to implement their professional ethics as CSR turned out to be a means of promotion that pictured the company have acted ethically, and the CSR also just become a strategic medium of PR in strengthening corporate power in society. This is what this paper attempts to explore the issue of public relations practices as a discourse technologist to perpetuate the organizational hegemony through CSR programs in the coal mining industry in East Kalimantan, Indonesia. The two Foucauldian themes on power and knowledge are the subject matter of this article. Drawing on the concept, this research will utilize Foucault's concept to examine the practitioners' experiences on the discourse of corporate social responsibility.

Public Relations in Foucauldian Perspective. Foucault brings such different nuances in the study of public relations related to the issue of power. As Trujillo and Toth (1987) state that organizations are an ideological arena for power, influence and control so that public organizations are defined as a coalition as well as constituents who shared the same needs, values and perspectives. Foucault critical approach investigates how political, socio-cultural and economic conditions shape the practice of PR (Holtzhausen, 2002) and determines the source of power and influence (Mickey, 1998) represented by PR practitioners. So it can be said that the PR practice itself is promoting certain values that in turn leads to the question on the PR involvement and its responsibilities they have within and to the democratic societies.

Therefore, the key to understanding how PR represents and promotes certain truths and powers is by examining the discourse strategies carried out by PR practitioners. In PR practice, discourse is mobilized as a political resource to influence public opinion as well as to achieve political, economic and socio-cultural transformation. In other words, a discourse can be considered as a series of statements, which according to Foucault (1996) consists of 'the existence of the rules of formation for all its objects, for all its operations, for all its concepts, and for all its theoretical options' (p.35). Hence, discourse is something that is both symbolic and constitutive in its arrangement of what we know, understand, talk about, and do in this world. As described by Fairclough (1992), discourse is a practice that not only represents the world but signifies the world in meaning (p. 64). Although not all experiences are explained through and by discourse (Finlayson, 2001), the main activity of public relations is to provide and to shape the meaning for social, cultural, politics, and economic experiences for the benefit of the organization it represents.

Public relations practitioners strategically disseminate certain text that facilitates certain socio-cultural practices and nothing else (Motion \& Leitch, 1996). Thus, based on Foucault framework, PRs are assumed to be trying to gain power for their clients by building a truth 
regime. The main strategic goal of becoming a 'voice of truth' is to get public approval for certain practices. So that the formation of a truth regime is related in a circle of relations with the power system that produces and maintains it, as well as the effects of power that causes and extends it (Foucault, 1972). Therefore, truth and power are closely related and function to strengthen one another.

Foucauldian Discourse Analysis. This study uses Foucauldian critical discourse to analyze data derived from interviews with public relations practitioners. Foucault considers his thoughts and research to be an attempt to open up the possibility of thinking in new ways: 'Writing in orders to change myself and in order not to think the same thing as before' (Foucault, 2001, p. 240). In other words, this Foucauldian discourse analysis is not an integrated or single approach as it does not have a fixed method such as other traditional experiments or content analysis. Potter and Wetherell (1987) stated that what researchers have is a broad theoretical framework related to the nature of discourse and its role in social life, along with various suggestions on how discourse can be learned.

Although this approach looks flexible, the flexibility itself means nothing. This is because the right approach requires a proper understanding of which tools to choose from Foucault' s idea to be applied in certain fields. In this study, the researcher explores how PR practices as a discourse technologist constructed by informants during interviews on CSR programs to shape company reputation by referring to the concept of discourse and Foucault's power-knowledge relationship. Based on Bowen (2008), this analysis emphasizes on how the conversation is produced. This is in line with Fontana and Prokos (2007) which underline the importance of understanding what is said as it relates to the experience of the informants and the context of the event.

As any other qualitative research, the personal assumption, knowledge, culture and experience of the researcher might influence the interview results. As well as the social role, social context, knowledge, culture, experience, and other values of the informants in their responses during the interview. Therefore, the active involvement of researchers with informants during data collection is particularly required to have a more reflective process when data is analyzed so then all possibilities that might affect the result construction. The dominant themes emerged from the interviews are given special attention, and at the same time, the analysis focuses on negative cases or unusual themes that offer alternative explanations.

It has been described how the analysis of the PR practices on the CSR programs will be approached; it is time to turn our attention to the substance of the analysis. However, it is necessary to provide some detailed background regarding the two mining companies subjected to this study and understanding its CSR programs as well as its social, economy, and political landscapes.

Coal Mining Industry in East Kalimantan, Indonesia. East Kalimantan, one of the richest province in Indonesia is currently supported by 45 per cent of the extraction industry, especially coal mining. This means that almost half of the economy driver and regional income are significantly influenced by the ups and downs of the coal production. When the coal prices skyrocketed like in 2011-2012 ago, the regional budget was like in its golden era. Conversely, when the coal prices declined, the development budget charts followed the same thing. The central, provincial and district governments have issued more than 1,400 mining licenses with an area of around 5.2 million hectares. Of this total, 506 mining licenses are already in the production stage and another 406 licenses are later revoked due to administration issues.

However, the negative impact is still running with the opening of the catchment area, the mine pits require billions of rupiah recovery funds while the reclamation guarantees had not run well before. The potential for flooding and death in the pit is very detrimental to the community living around, it goes beyond the regional expenditure budget in handling it. Whereas East Kalimantan statistically produces an average of 200 million metric tons of coal per year or around 40 per cent of national production. If 200 million metric tons are multiplied by medium coal prices of US\$ 45 per ton, then the gross revenue will be of US\$ 9 billion or around IDR 126 billion (with the exchange rate of 14,000 = US\$1). Assuming a net profit of 
20 per cent, it is estimated that it will reach around IDR 25,2 trillion or six times of the provincial income budget). However, from this huge income plus oil and gas as well as others, East Kalimantan only receives IDR 4 trillion funds on average for each year, while the rest is donated to the state. Yet the environmental impact is only felt by the locals, and the development has not been fully prospered the community.

On the other hand, two of the largest coal producer companies in Indonesia, are located in East Kalimantan. Namely, PT Kaltim Prima Coal (KPC) located in East Kutai District, and PT Berau Coal Energy which is in Berau District. These two coal mining companies are considered as the role model in CSR initiatives due to various CSR award that they have received both at national and international levels. In 2017 the two companies are among the three recipients that received the GOLD PROPER award from the East Kalimantan provincial government which is the highest category for the implementation of corporate sustainability programs. Meaning both companies have a comprehensive policy framework related to CSR initiatives compare to other coal mining companies in the place. They have a number of policies covering various subjects such as environmental policy, health and safety, energy use and communication which are the core business of CSR.

PR Practice: Promoting CSR for the Existence and Power of the Company. In the context of PR practices as a discourse technologist, it can be summarized from the shared agreement of the 12 informants of the two companies that the main task of PR practitioners is to promote their CSR programs. Repetition of these keywords found in existing texts to describe the importance of these practices such as 'highlighting' 'telling', 'talking', 'campaigning', 'celebrating', 'communicating', 'introducing', and 'repeating'. Those terms are used by a majority of informants to describe the urgency of public relations practice to promote the CSR programs implemented by companies. In this context, promotional repertoires are used to emphasize PR practices in promoting CSR programs messages to convey information to stakeholders, including the public that the companies have done good deeds through the initiatives.

In addition, it is important to underline that the enthusiasm of the informants to promote the companies' CSR programs were also very apparent during interviews. The researcher feels that majority informants are very passionate about the subject being discussed. The informants used every opportunity to explain various CSR programs initiated by the companies. The promotion practice appears through various repetitions through the terms 'communicating', 'sharing', and 'marketing'. The first two keywords explain the act of sharing information by providing information to other parties. Nevertheless, according to Kasabov (2004) who was inspired by Foucault, the term 'market' historically tended to describe a form of power because it is an instrument of social control that seizes attention discipline through spectacle, sensations and repetitive information conveyed. This can later be interpreted that PR is strategically spreading CSR discourse so it produces positive impacts on the interests of the company, such as generating media coverage or building a reputation which is profitable for the companies. In this case, the PR practice on promoting CSR programs aim to advance the companies' mission as interpreted as one of the main functions carried out by the informants.

There are a number of promotional markers that illustrate the act of promoting CSR programs done by the informants during interviews. The Acting Manager of Community Empowerment KPC for example started by showing the PR obligation to communicate CSR programs by expressing 'PR is the party who should always use every opportunity so that the CSR programs we have is known by the public!'. A variety of different communication methods were later raised to describe the strong and persuasive intentions to promote CSR programs. The act of promoting CSR seems to be echoed, with terms such as 'to be known' and 'to be acknowledged', all of which are framed mainly to attract public attention regarding CSR programs in order to achieve certain goals. This shows that PR is in a position to exploit CSR programs to create greater awareness to a wider audience on behalf of the company. On the other hand, the phrase 'to report' is relatively similar to the keywords used by PR officer of Berau Coal Energy such as 'to tell', 'to talk', and 'to share information' which emphasise the information dissemination to inform the public. Such communication model is 
alike to Grunig's public information model (1992) where the main goal is to inform corporate stakeholders about CSR programs although not persuasively. This shows that PR uses various types of communication media to spread certain discourses in order to reach the companies' stakeholders. To this point, it is argued that the PR practice is largely constructed to create greater awareness than just announcing all things related to corporate responsibility practices, which most of it aims to create benefits for the companies.

The creation of awareness regarding CSR programs to pursue corporate interests has been discussed in various works of literature. A number of studies reveal that the low awareness of stakeholders on the company's CSR programs might hinder the efforts to gain strategic benefits (Sen, Bhattacharya \& Korschun, 2006; Singh, Sethuraman \& Lam, 2017; Wong \& Danesh, 2017). However, they also stress that stakeholders sometimes respond skeptically to the aggressive CSR program promotions done by the company. In this case, it is important to ensure that CSR programs carried out bring substantive changes in accordance with the needs and expectations of constituents, and not merely symbolic to control public perceptions.

Furthermore, the implication if not involving PR in the CSR programs also draws the researcher' attention. Community Development Manager BCE stated that CSR could actually be carried out without any PR intervention but it seems to be such the 'unsung heroes' who did not receive any recognition for what has been done. In this context, the 'unsung heroes' will depend on the third parties to appreciate the good that has been done. In other words, the corporate active involvement in CSR initiatives that are not known by the public will become an initiative that does not provide any benefits to the company.

On the other hand, External Relations Manager KPC marks another effect that might be presented when the company did not publish their CSR programs to the public. He expresses his belief in the ability of PR in communicating CSR-related information through phrases such as 'we must spread' and 'we can bring up'. Even so, the word 'bring up' sometimes gas a negative connotation because it is considered as a manipulative or hyperbolic type of communication. In addition, the term 'bringing up' implies the PR practice as a communication technologist is the one responsible for selecting and designing CSRrelated messages to take advantage of the CSR program' impacts and represent the unethical communication practice. Meanwhile, the phrase 'So when we do a good thing, at the same time we need to spread it out so people know that we are doing good, you know' shows the great desire for the CSR programs to be acknowledged by other parties. In addition, he supports the notion that CSR programs must be implemented explicitly to avoid company being considered to be selfish or merely wishing to generate financial profit and not truly want to give back to the community. In other words, the company is only 'doing good to look good'. He illustrates this in the following expression: 'If not, the public will say that KPC is just like other mining companies and never gives anything'. The term 'public' used in the quotation represents the community or company stakeholders who are considered to be more likely making accusations as stated by the informant.

Up to this point, the PR practices in promoting CSR programs are used to recognize the importance of doing good things that later explicitly used to ensure public recognition for the benefit of the company. At the same time, PR practice in promoting CSR is to make their responsible practice more explicit and thus helps counteract the negative public perception. By showing off the company's contribution made for the community, in other words, will prevent the public from having negative respond. This is in line with Orlitzky, Schmidt and Rynes (2003) statement which emphasise that the lack of effort in communicating the company's social initiatives will eventually create a negative perception on the company's activities.

The promotional practices are constructed as an attempt to build a positive image in order to maintain the company's existence as desired as described by the Specialist Reporting and Data Management KPC. Some expressions such as 'want to be highlighted' and 'tell to all parties' illustrate the informant' desires to promote CSR programs to the public at large. He firmly separates the intention to promote good deeds (in this case is CSR) by merely boasting '..has implemented this and that kind of CSR program, but not in the context 
of boasting, you know..but to show them that we are different'. This shows that PR practitioners are well aware that corporate programs such as CSR can easily be misinterpreted as mere show-off activities which later create public skepticism. This is important for the company to note since the public skepticism tends to create a negative response to other activities implemented by the company (Elvig, 2010) which of course can be detrimental to the company's image. Community Development Manager BCE also emphasizes the intention to do good things on the phrase 'to states that we are responsible' and 'that we actually help'. Those expressions try to emphasize their noble intention to meet the need of other parties and not just the pursuit of their interests.

The statement of the Specialist Reporting and Data Management KPC also explained the PR practice in promoting CSR programs illustrate how the programs were implemented to secure the image as expected. This was clearly stated in his sentence: "... with the existence of PR, of course, to promote the company's CSR programs so that it can get a place that is expected for the company's sustainability". The informant very clearly illustrates the PR practices utilising the CSR program' discourse to acquire a particular image as desired for the company's interests. This practice is a clear example of how PR uses CSR merely as a tool to improve reputation. Some scholars argue that CSR becomes an important element that contributes to the formation of company's positive reputation (Schnietz \& Epstein, 2005; L'Etang, 2009; Du, Bhattacharya \& Sen, 2010; Mackey, 2013) thus they emphasise the importance of CSR discourse. Michaelson and Stacks (2014) further affirm that reputation is formed through words and actions both individually and organizationally, as well through relationship and experiences possessed by other people related to such individual or organization. In this case, promoting responsible practice then becomes an integral part of the process. This is in line to what is argued by the researcher that PR acting as a discourse technologist is substantively and actively involved in the production and distribution of the discourse texts, as well as serves in the interest of the organization in which s/he works for. Up to this point, this case affirms that the PR practitioners work in the coal mining industry in East Kalimantan are positioned in a strategic one serve to spread CSR discourse to construct a favorable image for the sake of maintaining the companies existence and power.

In the context of critical PR, its authority to create and control information should be accompanied with ethical considerations which include providing balanced and accurate information that helps all stakeholders make the right decisions. There are a number of ethical debates related to company activities in communicating a truth by saving other ones. L'Etang (2004) states that holding back information clearly violates the public interest and clearly shows that PR ethics is largely governed by those who pay them. Furthermore, L'Etang (2009) and Mackey (2013) also argue that using programs just to achieve company goals, making PR practices immoral since they are considered disrespectful to the beneficiaries (which in this context can be interpreted as the society). This certainly raises particular concern for the imbalance profits acquired by the company and the share received by the targets of CSR programs. Therefore, it is argued that the CSR program use only as a tool for PR practice might create a negative impact on the recipients, as well as the lack of attention that should be given to addressing their actual needs at the first place. This is because the plans made by the company could be more devoted to simply generate publicity for the sake of the company's image.

In addition, PR practitioners on many occasions also acknowledge their involvement in CSR promotion more like the strategic matter as they work for the benefit of those who pay them. Then it can be said that PR serves more as a strategic resource to help organizations achieve their only interests. The strategic Relations Officer of BCE affirms that making CSR programs popular among the public was very important to produce a positive business outcome. He states this statement very clearly in his answer by saying "Particularly the public at large, they should know that we have done good things. So our potential investors are sure about our company. Or how can we assure the government as well that we have already helped them?". In this context, this informant does not really believe that company might gain benefit from their CSR programs if it does not know by their strategic publics, 
such as investors and government. This text gives the impression that PR practice in the context of CSR promotion is very strategic as it is used to maximise the value for the company, especially to gain trust among potential investors and the government. In other words, PR plays a strategic role while dealing with various efforts that might produce a particular impact aimed by the company.

Likewise with the term 'strategic' which is repeatedly used by the External Relations Supervisor of KPC to emphasize that PR works for the interests of the company. He states that PR ability is to create a positive impact on the company and it includes a strategic value of media coverage. According to Foucauldian, PR should make a number of efforts to evaluate their strategic actions to show their true value not only for the management but also to the public as PR is actually considered as a social activist (Coombs \& Holladay, 2012). In this case, this situation makes them a real discourse technologist serve for the company only, as in most of the interviews done throughout the study the majority of informants describe the PR practice more about promoting CSR and left the issue of the actual needs of the external public.

At the macro level, CSR is generally constructed as a business component that helps the company remain competitive in its business. Making CSR programs reports also serves more as an indirect approach to instilling responsible behaviour among business actors. This is because this corporate responsibility practice is perceived as an important element to attract potential investors and get larger valued business contracts. As a number of institutions at national and international levels award companies that continuously implementing CSR programs (such as Asia Responsible Entrepreneurship Award, Indonesia Corporate Social Responsibility Award, Global CSR Award, Sustainable Development Goals Award, Nusantara CSR Award, and Environmental Award), it then creates a competition between companies to publish their social performance programs. The recognition and spotlight given by media are considered playing as an active driver for the company promoting their CSR to external public. Therefore, it is becoming important for the public is critical to watch on the CSR programs since according to Sandoval (2013) in many cases the CSR actual practices do not correspond to the company's reputation built in the media.

Gaining recognition from the stakeholders related to CSR programs is considered crucial for the existence and reputation of mining companies. This is particularly true since the high criticism pointed to the mining industry which is vulnerable to conflict as well as environmental and social issues. The award and publication of CSR programs received by the mining companies are explained by Jenkins and Yakovleva (2006) as a way to overcome negative public discourse on the mining industry. For functionalist scholars, this matter shows that mining companies seek to be part of good corporate citizens through their CSR programs (Ranangen, 2015). However, in Foucauldian perspective, public attention and news exposure on the company's CSR programs are often associated with the power to build an image of success. In this case, these two mining companies persistently promote their social responsibility practices to create positive discourse for their competitive advantage. In doing so, it is found that the PR practice in promoting CSR programs is largely influenced by the pressures and expectations indirectly made by the CSR proponents, namely the government and other CSR implementing agencies. So the CSR programs as part of PR practices were initiated to compromise with the interests of the dominant groups over the interests of other parties.

Up to this point, it can be said that the PR practice in promoting CSR largely led to the company's interests and not truly true in the public interest. This study found that the majority of informants of both coal mining companies in East Kalimantan is rarely talked about their position in the CSR promotion in order to help to cope with the actual needs of the community. PR practitioners generally act as institutional texts that present to teach corporations on how to create its identity for the sake of getting a positive image from the public and to gain legitimacy by using a variety of strategies, including its social programs as well as the creation of corporate narratives.

PR Practice: Playing Advisory Role for the Social Programs. The other dominant patterns found in the texts indicate that PR plays an advisory role in CSR-related programs. 
This practice arose because PR in both companies were not in a pioneer position in CSR programs. Some key phrases such as 'giving consent', 'monitoring', 'being approved by PR', and 'PR present to give advice' indicate that PR has a certain level of expertise and power in CSR implementation. PR practitioners exercise certain powers related to the access they have to scarce resources and the closeness of network with the organizational management as confirmed by Grunig, Grunig and Dozier (2002). These rare resources are communication and environmental scanning skills that make PR involvement is perceived as crucial. In this case, PR practitioners are considered to have a level of expertise that is difficult for others to replace. This ability is similar to the term power in Foucault (1980) political discourse which often brings the meaning of domination. The knowledge possessed by PR on communication management of CSR programs is something that creates both the power and the creator of power itself, as Foucault states that the exercise of power perpetually creates knowledge and conversely, knowledge constantly induces effects of power (Foucault, 1980, p. 52). From this perspective, PR is clearly regarded as the main actors in the power/knowledge process and through their role as discourse, technologist PR plays a strategic discourse related to CSR programs to achieve hegemonic status among the external public.

PR practice as an advisor in CSR programs emerged from the interview conducted both with PR and CSR practitioners. PR Officer of BCE acknowledged that her PR Division was not the spearhead of the CSR programs in the company where she worked. However, she identified that PR is considered to play an important role in CSR programs implementation. She acknowledges PR as the party responsible for giving approval for CSR programs when she stated "our division only approves of what needs to be done". The term 'approve' in this context implies that PR has the power to authorise the CSR programs which in this case, its approval is requested before the programs are organised, specifically ones that related to company image and identity. This is evident when the informant asserted that PR responsibility was to ensure that every aspect of CSR programs depicted the company's image as expected.

The Specialist Reporting \& Data Management of KPC also stresses the importance of PR practices in providing input related to CSR programs in line with the company's image. He emphasizes that the corporate's image and identity would be neglected if PR did not participate in the program. Negative phrases like "they will not be concerned to the issue of corporate image or identity" describe that CSR practitioners are not paying attention to image and identity when implementing CSR programs. In this case, based on the power of that provided by management, PR is responsible to guard the corporate image and reputation.

The Specialist Reporting \& Data Management of KPC also stresses the importance of PR practices in providing input related to CSR programs in line with the company's image. He emphasizes that the corporate's image and identity would be neglected if PR did not participate in the program. Negative phrases like "they will not be concerned to the issue of corporate image or identity" describe that CSR practitioners are not paying attention to image and identity when implementing CSR programs. In this case, based on the power of that provided by management, $\mathrm{PR}$ is responsible to guard the corporate image and reputation. This belief is also clearly reiterated by PR officer of BCE that PR was involved in decision making regarding CSR programs even though they did not lead the program implementation. This involvement is based on the trust given by the top management that always emphasises that "all programs must be discussed with PR" which indicates that PR is in a position to give 'approval' to CSR programs. This trust implies the attribution of power given to PR by the higher level of organization to PR to decide on various issues related to CSR. This is possible because of the involvement of PR is considered important in order to direct the CSR programs to fit the corporate image and identity. This reinforces the statement of Heller (2016) that PR uses a discursive strategy by creating narratives related to companies to create a positive corporate image and to deflect criticism by integrating the concept of corporate responsibility and goodwill discourses. The PR officer of BCE statement illustrates the PR involvement in CSR programs by saying "whatever the content of the programs must get approval from PR", "we were involved in many meetings", and "our input is needed" which mostly show that PR practice in CAR programs is considered significant per se. 
PR practice as an advisor in CSR programs was also acknowledged by BCE's CSR Manager. In the interview, he concedes the importance of PR in giving advice regarding CSR programs. His recognition of PR involvement in CSR programs is illustrated in the following phrase: "We need PR to be part of our team and to provide input on implementing these activities and projects...", and "PR must be there". In this case, PR involvement is perceived as crucial to ensuring the success of CSR programs. This shows that PR skills in managing programs, particularly when they involve public cannot be replaced by other parties. The power given to PR implies that other departments are considered less able to provide the same skills and advice. This is in line with Foucault that discourse is the centre of power and knowledge as well as influence the historical development of society, including corporations.

The interview with the Media Relations Supervisor of KPC likewise showed a strong dependence on public relations expertise, especially related to the communication things. The dependence of Sustainable Development Division conducting CSR to PR skills are described in the following phrase, "they need our help to communicate CSR", and "...we give advice on how they should relate with media". Those all show that the CSR Division seems to have less 'knowledge' or skills to communicate with the public, including the media. In addition, he also acknowledged the strong attachment between PR and the community when he stated, "We tell them what the community actually needs", and "We are considered to know the community and what they want". These words indicate the recognition of PR knowledge related to community relations and PR ability to identify what is needed by the community.

The BCE CSR-Community Plan and Control Supervisor also identified the importance of PR involvement in giving advice, specifically related to the field of communication. He acknowledges that there is a cooperative relationship between CSR and PR divisions, particularly related to the field of communication. He stated there is always a representative from PR department to be part of CSR team when he stated, "Our PR friends are also part of the CSR committee in Berau Coal". This explicitly illustrates that PR skills related to communication matter are highly valued and considered essential to ensure the success of CSR programs. At the same time, this response also shows that the CSR division' personnel have shortcomings in terms of communications skills, so they need PR assistance.

The PR practice as an advisor reveals the CSR division's dependence on PR, especially related to communication skills to the external public including the media. Allen (2016) argues that PR practitioners are the one who has communications skills and competencies related to CSR issues. He also stresses several reasons why PR should have a number of competitive advantages when compared to other scientific disciplines in terms of communicating CSR. One of them is their educational background and experience in communicating complex problems in various ways to diverse stakeholders, as well as personal knowledge related to stakeholders; "As boundary spanning is part of the daily routine of PR" (Allen, 2016, p. 66). In this case, unlike other workers, PR practitioners are considered capable of integrating diverse values and interests in the decision making process. Such special abilities are emphasized by Hargie and Tourish (2009) in his article that the thing distinguished a PR when he meets other professionals is his ability to bring up discussions regarding broader social issues, and the appropriate approaches to overcome these problems to the level of their implications in organizational behaviour and in the public sphere.

Mykkanen and Vos (2015) assert that corporate consulting services is one of the main functions performed by PR. This is associated with the PR function at a managerial level which provides the opportunity for practitioners to be involved in the decision-making process. Similarly, this study shows the PR practice as CSR advisor reveal a strong dependence on PR, especially in matters relating to communication problems and image building. It is assumed that the PR presence is considered important in terms of their involvement in CSR programs in both coal mining companies. As Pieczka (2006) emphasizes that PR expertise arises as a practical knowledge generated from the experience of these practitioners. This is what makes PR is regarded as a reliable discourse technologist who manages the company's public opinion. 
This shows that the reliance on PR regarding communication and image building issues implies that CSR programs might only be about creating a positive organizational image for the sake of the company, and not really aims to generate positive impacts on external stakeholders. This impacts on PR-related functions that it is so hard to dodge when many define PR as a corporate tool devoted to controlling information (Davis, 2002), or even equating them as propaganda machines (Sullivan, 2011) just to maintain clients' reputation. This is particularly true since most discussions to PR-related functions are more on image construction than other strategic activities. Therefore, PR should dare to take initiative to establish a responsible or a fairer communication related to both interests of the company and the community through appropriate research and evaluation related to various communication strategies implemented, including CSR programs. To prove that PR is not only a discourse technologist that works solely for the corporate's image and reputation.

Challenges for PR Practice. The importance of PR practice in promoting CSR and giving advice on CSR programs also raises some challenges in PR practice within the existing texts. This issue describes various factors explaining the limitations of current PR practice as CSR initiatives in Indonesia continues to grow beyond the social, politic and cultural dimensions. In February 2018 ago, the East Kalimantan Mining CSR Forum was inaugurated and then identified five key areas that should be emphasised, such as infrastructure, education, health, environment, and community economy as the company' priorities framework related to their social performance. Therefore, the terms such as corporate responsibility and social empowerment appear to represent a more holistic dimension that surpasses such existing issues. This is certainly posse a major challenge in PR practice related to CSR programs as well as criticism from Foucauldian on PR performance if the results obtained from the public involvement process has been predetermined. This is because in the end the efforts are done by the company only show a fierce manifestation of power designed to legitimise the discourse and position of the dominant coalition (in this case is the corporation).

The limited PR practice only as a discourse technologist in the context of CSR programs is illustrated by the Strategic Relations Officer of BCE and the Acting Manager of Community Empowerment of KPC in their interviews. Both informants somewhat describe the PR limitations on the CSR programs-related issues. he Strategic Relations Officer of BCE emphasises that the strategic function of PR in relations to CSR is related only on attracting more investment from shareholders. He firmly acknowledges that it is his division's responsibility to undertake this task when he stated that, "that is our responsibility!". He also gave an impression that there were limitation regarding to PR practice in CSR programs when he said: "Our CSR programs are devoted to activities and strategies to gain trust from the government and community, to attract more attention from the investors, potential investors, and other stakeholders so they will trust us more". This implies that PR practice on CSR programs is limited only to matters relating to stakeholders and reputation management to maintain the company's legitimacy and power. This also shows that the CSR programs implementation in coal mining companies in East Kalimantan, Indonesia is still subjected to large imbalances and structural misalignment, which although wrapped in corporate goodwill through PR discourse but are actually part of the global hegemony construction.

In addition, the Community Empowerment Acting Manager of KPC considers that the PR practice is only part of perceptual management when he stated: "PR is related to the problem of perceptual control". In this case, the dynamic of PR practice related to CSR programs is seen only as part of the organization's communication effort in managing relationships with its environment to achieve certain goals. The informant described a collaborative approach with other divisions to gather other information so that it could be further integrated into CSR programs. He also made it clear when he said "...we usually work together with all divisions for technical inputs for the progress of the company. Let's say, for example, HSES division told us that maybe we could do something for this community". In this case, PR actually needs to begin playing their social roles in a professional manner so that they would be acknowledged and considered capable of the creation and maintenance of a more prosperous society. 
Another interview also illustrates the informant' perception related to PR practice which may affect either the relationships with the company or the community. The Specialist Reporting \& Data Management KPC implicitly identifies PR as a division that costs money, and not a division that generates direct profits. The informant firmly stated that this ability through his phrase: ' ....a department that works on service functions of the company, not one that generates financially...". This assumption is a bit much further undermine the PR contribution in providing benefits to the company value or their ability to contribute strategically. Their inability to carry out these strategic functions prevents PR from giving more significant implications, not only to management but also to the wider community.

This idea led to another challenge that overshadows the PR practice related to their involvement in CSR programs implementation. This is related to the lack of resources, such as personnel number, time and financial factors that hinder the PR practice in the long term. The PR Officer of BCE indicated the PR commitment to be actively involved in PR programs even though the company has a separate CSR division. The fact that such CSR programs are recognised to have been implemented since the company's inception, she identifies a number of challenges if PR become the pioneers of CSR programs by saying "these kinda programs take a lot of our time", and "there are many programs to be implemented". Related to this statement, this informant acknowledges the limited resources of PR to overcome the high intensity of CSR programs. The PR limitations to be able to really focus on CSR programs are probably one of the reasons why the management separates the CSR division from PR. As illustrated by the Supervisor Media Relations of KPC, the lack of energy and time are some important issues that challenge the PR to be fully involved in CSR programs effectively. Such challenges arose in the following phrases: "It is important to have a fully dedicated staff", "we don't always have time to sit together and draw up a strategy", and "sometimes it seems we are becoming very ad-hoc". In this case, limited personnel are considered to influence strategic CSR program planning. This further implies that CSR programs are considered significant for the existence of coal mining companies, where the modest and well-turned programs actually do not adequately reflect CSR initiatives that are relevant to contemporary social change. Therefore, the large coal mining companies such as $\mathrm{BCE}$ and KPC have a separate department that is specifically responsible for managing CSR programs.

Apart from the main idea underlying CSR movement as one form of corporate responsibility to pursue their financial goals, the CSR programs' success themselves must be supported by adequate resources. The PR Superintendent of BCE uses the term 'sincere' and 'truthful' which describes the amount of commitment they have in carrying out CSR programs. He also stated that the pure CSR requires continuous and long-term involvement with different stakeholders which creates a particular obstacle for PR division if they have to handle it all alone. He acknowledged that this challenge is related to the limited number of PR personnel who are able to carry out all matters related to corporate communication in the company he works for. At the same time, he also admits the importance of stakeholder involvement in CSR program implementation which requires intense and long-term communication. Whereas according to Pieczka (2006), the PR ability to engage in a dialogue effectively is considered as the major activity that requires stakeholder involvement. Pieczka (2006) emphasises that in many situations the dialogue conducted by PR is difficult to understand, and then also followed up in a limited manner both theoretically and practically. In the end, it can be affirmed that CSR programs, in the long run, require more resources, financially and non-financially, which is also considered as another big challenge for the PR division. Therefore, it is argued that PR does not merely considered CSR as part of the company publication, but also have to ensure that all stakeholders (both internal and external) are aware of the commitments and efforts made by the corporations. In other words, PR practice is supposed to be a vehicle capable of enlightening and sharing information the progress made by companies that embrace CSR programs in a strategic and integrated manner. 


\section{CONCLUSION}

This article discusses the dominant themes that arise in the study conducted with PR and CSR practitioners in two major coal mining companies in East Kalimantan, Indonesia related to PR practice as a discourse technologist in CSR programs implementation. The discussion above help explains the PR practices as a discourse technologist that manifests in the form of intense CSR programs campaign that are implemented for the sake of companies that appear dominantly in the existing interviews. Although in both companies CSR was managed by a specific division, the PR practice manifests in through the CSR division' needs for PR advice related to CSR' decision making and promotion as revealed by the informants.

As a discourse technologist, the most sought-after from PR is certainly some advice related to communication as well as the formation of identity and image related to CSR programs, which seems to undermine other PR analytical skills. This illustrates that PR should try more to show their actual contribution both to the company and society. The dynamic development of CSR and the vulnerability of the coal mining industry make PR work by playing a discourse on CSR programs. This is done to demonstrate the public that the companies commitment are not only limited to matters related to profit. However, this is also a challenge for PR if it is not considered a threat related to PR function which should spearhead the creation of CSR initiatives that are in accordance with business ethics standards.

The discussion above shows the tendency of PR to reduce their professional values related to the implementation of CSR programs to main the dominant power, namely corporate interests which affect the scope of PR practices. For example, the PR practice is often equated with PR strategies and limited only to control the perception so that it hardly sees how PR might contribute to the company and society at large. It then weakens the real PR values in the context of organizational functions, including CSR-related programs. Therefore, it is strongly encouraging to PR practitioners to demonstrate their value by providing evidence of concrete work capabilities and not only being trapped in the management function of CSR discourse for the benefit of the company. It is however important for PR to be able and be brave to implement CSR that benefits both the corporation and the society. Hence, it is time for PR to reflect their practices for every action taken both for the company, the community and their profession as a whole.

\section{REFERENCES}

1. Allen, M. (2016) Strategic Communication for Sustainable Organization, Heidelberg, Springer.

2. Apriando, T. (2018), 'Nyawa Hilang di Lubang Batubara Bertambah, Aktivis Lingkungan Dapat Teror and Serangan', MONGABAY, accessed 10/11/2018 at http://www.mongabay.co.id/2018/11/29/nyawa-hilang-di-lubang-batubara-bertambahaktivis-lingkungan-dapat-teror-dan-serangan/

3. Bowen, S.A. (2008) 'A State of Neglect: Public Relations as 'Corporate Conscience' and Ethics Counsel', Journal of Public Relations Research, Vol. 20, pp. 271-296.

4. Coombs, W. \& Holladay, S. (2012) 'Fringe public relations: How activism moves critical pr toward the mainstream', Public Relations Review, Vol. 38, No. 5, pp. 880-887.

5. Davis, A. (2002), Public Relations Democracy: Politics, Public Relations and the Mass Media in Britain, New York, Manchester University Press.

6. Fairclough, S. (1992) 'Discourse and Text: Linguistic and Intertextual Analysis', Discourse \& Society, Vol. 3, No. 2, pp. 193-217.

7. Finlayson, A. (2001) 'Philo and Miller's metaphysical media studies', Media, Culture \& Society, Vol. 23, Iss. 5, pp. 679-687.

8. Fitryarini, I., Juwita, R. \& Purwaningsih (2015), Manajemen Komunikasi Konflik Paska Tambang Batubara di Kalimantan Timur, Hibah Penelitian DIKTI, Universitas Mulawarman. 
9. Fontana, A. \& Prokos, A.H. (2007) The Interview: From Formal to Postmodern, Left Coast Press Inc., California

10. Foucault, M. (1972) Archeology of Knowledge: And The Discourse on Language, New York, Pantheon Books.

11. Foucault, M. (1996) Discipline and Punish: The Birth of the Prison, New York, Vintage Books.

12. Foucault, M. (1980) Power/Knowledge: Selected Interviews and Other Writings 19721977, New York, Pantheon Books.

13. Foucault, M. (2001) Power: Essential Works of Foucault 1954-1984 Vol. 3, Faubion (Ed.).

14. Grunig, J. (1992) Excellence in Public Relations and Communication Management, New York, Routledge.

15. Grunig, L., Grunig, J. \& Dozier, D. (2002) Excellent Public Relations and Effective Organizations, London, Routledge.

16. Heller, M. (2016) 'Foucault, Discourse, and the Birth of British Public Relations', Enterprise \& Society, Vol. 17, No. 3, pp. 651-677

17. Holtzhausen, D. (2002) 'Towards a Postmodern Research Agenda for Public Relations', Public Relations Review, Vol. 28, No. 3, pp. 251-264.

18. Jaringan Advokasi Tambang (JATAM) (2016) 'KemenATR/BPN Dituntut Terbuka', diakses pada 28 Januari 2017 di https://www.jatam.org/kemenatrbpn-dituntut-terbuka-2/

19. Jenkins, H. \& Yakovleva, N. (2006) 'Corporate Social Responsibility in the Mining Industry: Exploring Trends in Social and Environmental Disclosure', Journal of Cleaner Production, Vol. 14, pp. 271-284.

20. L'Etang, J. (2004) Public Relations in Britain: A History of Professional Practice in the 20th Century, New Jersey, Lawrence Erlbaum Associates Publishers.

21. L'Etang, J. (2009) 'Public Relations and Diplomacy in a Globalised World: An Issue of Public Communication', American Behavioural Scientist, Vol. 53, no. 4, pp. 607-626.

22. Mackey, S. (2013) 'A Sophistic Rhetorical Approach to Public Relations', PRism, Vol. 10, No. 1, pp. 1-14.

23. Michaelson, D. \& Stacks, D. (2014) A Profesional and Practitioner's Guide to Public Relations Research, Measurement, and Evaluation, New York, Business Expert Press.

24. Mickey, T. J. (1998) 'Selling the Internet: A cultural studies approach to public relations', Public Relations Review, Vol. 24, pp.. 335-349.

25. Mykkanen, M. \& Vos, M. (2015) 'The contribution of Public Relations to Organizational Decision Making: Insight fromt the Literature', Public Relations Journal, Vol. 9, No. 2, pp. $1-17$.

26. Motion, J. \& Leitch, S. (1996) 'A Discursive Perspective from New Zealand: Another World View', Public Relations Review, Vol. 22, No. 3, pp. 297-309.

27. Motion, J. \& Weaver, C.K. (2005) 'A Discourse Perspective for Critical Public Relations Research: Life Sciences Network and the Battle for Truth', Journal of Public Relations Research, Vol. 17, No. 1, pp. 49-67.

28. Orlitzky, M., Schmidt, F. \& Rynes, S. (2003) 'Corporate Social and Financial Performance: A Meta-Analysis', Organization Studies, Vol. 24, No. 3, pp. 403-441

29. Potter, J. \& Wetherell, M. (1987) Discourse and Social Psychology: Beyond Attitudes and Behaviour, London, SAGE.

30. Pieczka, M. (2006) 'Paradigms, System Theory and Public Relations' dalam L'Etang, J. \& Pieczka, M. (Eds.) Public Relations Critical Debates and Contemporary Practice, London, Lawrence Erlbaum, pp. 331-358.

31. Ranangen, H. (2015) 'Corporate Social Responsibilty Practice in Mining Industry', Tesis Master of Industrial Environmental Management, Lulea University of Technology.

32. Republika (20 Februari 2018) 2017, Produksi Batu Bara di Kaltim Mencapai 82 Juta Ton,

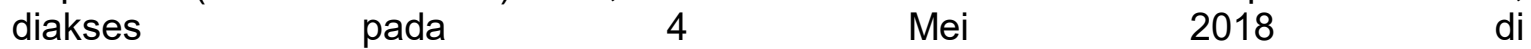
https://www.republika.co.id/berita/ekonomi/migas/18/02/19/p4e1zd368-2017-produksibatu-bara-di-kaltim-mencapai-82-juta-ton/

33. Sandoval, M. (2013) 'Corporate Social (IR)Responsibility in Media and Communication Industries', Javnost - The Public, Vol. 20, No. 3, pp. 39-57. 
34. Schnietz, K. \& Epstein, M. (2005) 'Exploring the Financial Value of a Reputation for Corporate Social Responsibility During a Crisis', Corporate Reputation Review, Vol. 7, No. 4, pp. 327-345.

35. Sen, S., Bhattacharya, C. \& Korschun, D. (2006) 'The Role of Corporate Social Responsibility in Strenghtening Multiple Stakeholder Relationships: A Field Experience', Journal of the Academy of Marketing Science, Vol. 34, No. 2, pp. 158-166.

36. Singh, P., Sethuraman, K. \& Lam, J. (2017) 'Impact of Corporate Social Responsibility Dimensions on Firm Value: Some Evidence from Hongkong and China', Sustainability, Vol. 9, pp. 15-32.

37. Suastha, R.V. \& Kandi, R.D. (2016) ‘Eksploitasi Batubara, Kutai Kartanegara Rugi Rp581 Triliun', CNN Indonesia, diakses pada 27 Januari 2017 di http://www.cnnindonesia.com/nasional/20160907001450-20-156556/eksploitasibatubara-kutai-kartanegara-rugi-rp581-triliun/

38. Sullivan, J. (2011), 'PR Industry Fills Vacuum Left by Shrinking Newsrooms', ProPublica, accessed 02/05/2018 at http://www.propublica.org/article/pr-industry-fills-vacuum-left-byshrinking-newsrooms

39. Tribun Kaltim (2016, 20 Juli) 'CSR Sektor Batubara di Kaltim Mencapai Rp 240 Miliar', accessed 29/01/2017 di http://kaltim.tribunnews.com/2016/07/20/csr-sektor-batubara-dikaltim-mencapai-rp-240-miliar

40. Trujillo, N. \& Toth, E.L. (1987) 'Organizational Perspectives for Public Relations Research and Practice', Management Communication Quarterly, Vol. 1(2), pp. 199-231

41. VOA Indonesia (2013, 4 Desember) 'Eksploitasi Batu Bara Rusak Kalimantan', diakses pada 28 Januari 2017 di http://www.voaindonesia.com/a/eksploitasi-batu-bara-rusakkalimantan/1803156.html

42. Wong, J. \& Dhanesh, G. (2017) 'Communicating Corporate Social Responsibility (CSR) in the Lux Industry', Management Communication Quarterly, Vol. 3, No. 1. 